\title{
IMPLEMENTATION OF CREATIVE ECONOMY ENTREPRENEURIAL CHARACTER DEVELOPMENT THROUGH THE CULTURE OF SUSTAINABLE DEVELOPMENT AND VOCATIONAL STAKEHOLDERS PARTNERSHIP
}

\author{
I Gusti Kade Siladana \\ Universitas Negeri Yogyakarta \\ Putu Sudira \\ Universitas Negeri Yogyakarta
}

\begin{abstract}
This ethnography research aims to find the concepts and implementation in developing creative economic entrepreneur characters through sustainable development culture and stakeholder partnership in vocational high school (VHS). Research data were collected inductively through indepth interviews, participant observation, documentation study, and internet site tracing based on research questions in the data generation manual. The data from the finding were interpreted deductively through coding process, and crystallization to produce informants shared cultural pattern and values, including (a) three sequences of life-based learning; (b) taksu's entity of creative economy; (c) seven perspectives for developing entrepreneurial characters (SEMESTA); (d) catur guru's essential enculturation for sustainable development and stakeholders partnership in vocational high school (VHS).
\end{abstract}

Keywords: creative economy, entrepreneurial character, sustainable development, stakeholder partnership

Permalink: http://dx.doi.org/10.21831/jpv.v9i2.24354

Contact I Gusti Kade Siladana

gk.siladana@gmail.com

-Department of Technology and Vocational Education, Graduate School of Universitas Negeri Yogyakarta Jl. Colombo No. 1, Karangmalang, Depok, Sleman, Yogyakarta 55281, Indonesia 


\section{INTRODUCTION}

The existence of vocational high school (VHS) or Sekolah Menengah Kejuruan (SMK) graduates as the highest contributor to the open unemployment rate among graduates of other educational institutions based on data from the National Statistics Agency raises a big question mark about the role of VHS in preparing graduates who are ready to work in business and industry. It is known that the open unemployment contribution of graduates from VHS, based on the data in February 2015 and August 2015 , was $9.05 \%$ and $12.65 \%$. The data on the unemployment contribution of VHS graduates in February 2016 and August 2016 were 9.84\% and $11.11 \%$, from the national open unemployment rate (The Central Bureau of Statistics, 2016a). Besides, within the scope of the Province of Bali, the contribution of VHS graduates for the open unemployment rate in February 2015 and August 2015 was $0.24 \%$ and 3.62\%. The data on the open unemployment contribution of VHS graduates in February 2016 and August 2016 were $3.01 \%$ and $3.96 \%$ (The Central Bureau of Statistics, 2016b).

To overcome this problem, it is not wise to charge the VHS parties working alone. However, collective awareness is needed to help provide analysis, suggestions, and alternative solutions for solving the problem of open unemployment graduates of these VHS. All parties should try to look at these labor issues comprehensively and analyze their determinant factors holistically. Furthermore, collective awareness contributes to concrete thoughts and actions to unravel the labor problems.

Some factors that are thought to be the causes include: (1) the gap in the number of vocational school job seekers with the number of available jobs; (2) the existence of skills mismatch or incompatibility between competency profiles taught in VHS with demands on work competencies (industrial skills and entrepreneurship); (3) the entrepreneurial character has not been formed and inadequate creative economic insight among the VHS graduates; (4) the culture of sustainable development has not been established in all elements of the implementation of vocational education; and (5) systemic synergies have not been formed among the elements of VHS stakeholders. For this reason, a comprehensive study is needed to reveal the praxis of the character development of creative economic entrepreneurship, a culture of sustainable development, and synergy in VHS stakeholder partnerships. Furthermore, the findings will result in the crystallization of patterns, shared culture and values, which become the basic concepts, formulation of ethic rules or indicators, and technical implementation of concepts and rules that are evident in the implementation of vocational education.

\section{RESEARCH METHOD}

This research is qualitative ethnographic research. Ethnographic research is essentially trying to uncover facts based on the perspective of informants or insider's perspective of reality (Fraenkel, Wallen, \& Hyun, 2012; Given, 2008). This ethnographic research aims to explore the meaningfulness or philosophy behind social facts or symptoms of creative economic entrepreneurial character development, enculturation of sustainable development, and stakeholder partnerships that occur in the vocational environment through various data selection methods and carried out in a participatory manner. In other words, researchers blended and dissolved in the social experience of the community or became an integrated part of the community. The subject of this ethnographic research includes all members of the stakeholder community of SMKN 3 Tabanan and SMKN 2 Sukawati. The selection of informants was not based on proportional samples but based on their capabilities in providing information that supports the building of research theory. This ethnographic research was carried out for approximately eight months, from November 2016 to June 2017.

The main instrument in ethnographic research is the researchers themselves concerning the guidelines of the research data generation manual. Data generation was done inductively by referring to research questions. The method of generating data used includes (1) indepth interviews; (2) participatory observation; (3) documentation; and (4) internet site tracing. Furthermore, the interpretation of findings data was made deductively, to produce crystallization of patterns, shared culture, and values in the context of vocational education. The crystallization of the pattern was carried out by applying the rules of cluster K mindset, namely the Idealization of Integration mindset. The characteristics of the $\mathrm{K}$ cluster mindset include 
rules of mindset: (1) correspondence; (2) relevance; (3) convergence; (4) gestalt; (5) integration; (6) triangulation; (7) synchronization; (8) congruence; (9) concurrency; (10) harmonization; (11) conformity; (12) coherence; and (13) morphogenetic, among data elements of research findings (Muhadjir, 2011).

\section{RESULTS AND DISCUSSION}

\section{The Concept and Implementation of VHS}

The finding data show that the basic reference to the concept of implementing vocational education is the creation of graduates who have the adaptive capacity in a career in the world of work and the world of entrepreneurship which is very dynamic and also provides an opportunity to continue to a higher level of education. The data finding is reflected from participatory observation in classroom learning activities, labs or workshops, partner industries, school libraries, and studies of VHS curriculum documents (the curriculum books, competency structures, syllabus and also learning implementation plans or lesson plans).

The finding data were then followed up by in-depth interviews with several key informants related to the meaning of the observed symptoms of participatory observation data and document studies to obtain the perspectives of the actors of these educational activities. The aim is to explore the concept of implementation, describe the actualization of the concept to the level of implementation, and how they assess the level of compatibility or harmony between the concepts and implementation.

The findings of the three methods are then crystallized by applying the idealization mindset of integration. The crystallization results in the main hierarchical structure in the vocational curriculum, in which the research consists of four skills groups, including (a) fundamental skills; (b) generic-work skills; (c) industry-specific skills; and (d) employer-specific skills. Fundamental skills and genericwork skills groups are given in order to equip graduates with adaptation skills (soft skills). The description of fundamental skills includes: first, basic skills such as the ability to listen, read, write, speak; second, high order thinking skills such as creative thinking, critical thinking, critical decision making, and problem solving; and third, personal qualities such as responsibility, integrity, self-confidence, morality. The next skill group is generic-work skills, including the ability to use resources utilization, information processing, technology mastery, system understanding, communication, and collaboration skills (team working). Meanwhile, industry-specific skills and employer-specific skills are given in order to equip students to be able to work in certain industrial clusters, as well as skills in working on the specific tasks of the certain industrial sub-section (hard skills).

Furthermore, in the implementation of vocational education in VHS, the pattern of learning orientation movement was in spiral sequential (mosquito repellent), moving from an expert-centered learning paradigm held in classrooms or school labs. Then it extends to the work-oriented learning skills paradigm, namely work-based learning in schools and workplace learning in business and industry, which is facilitated by project-based or workbased scaffolding. Scaffolding means that the level of guidance in the project work is reduced or released step by step gradually. Moreover, the latter extends to the life-based learning paradigm, through extracurricular activities, social inquiry, interactive discussions, activities in the production and service units. Based on the results of participatory observation, the learning process occurs independently (selfdirected) or on-demand based on the student's needs and continuous inquiry. The orientation is so that graduates can always adapt to the dynamics of technological developments in the world of work. Further, graduates will be able to survive in solving their own life problems. The concept and implementation of vocational education, where the research takes place, turns out to follow the pattern as seen in Figure 1.

\section{Concept and Implementation of Creative Economy Entrepreneurial Character Devel- opment in Vocational Schools}

Based on the results of interviews with several key informants, it was obtained an indication that creativity and entrepreneurship are the basic capital of developing creative economic entrepreneurial character. In fact, some informants saw creativity and entrepreneurship from the local wisdom of Balinese 

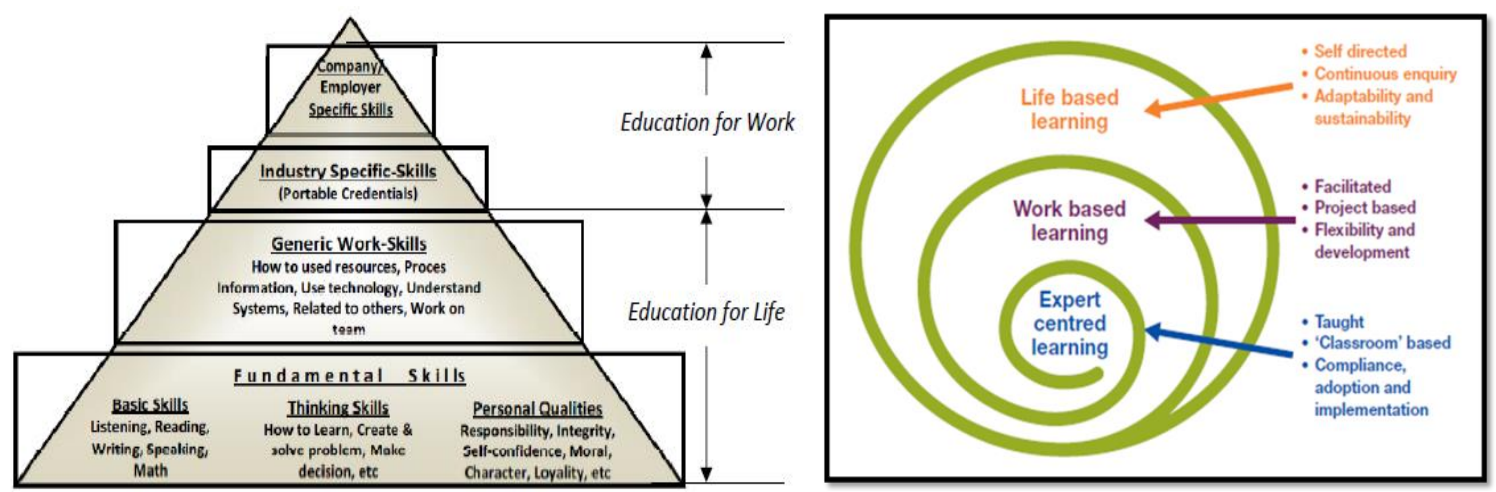

Figure 1.Structure of the Curriculum Hierarchy and Sequence of Movement of the Vocational Life-Based Learning Paradigm.

Source: adapted from Sudira (2016)

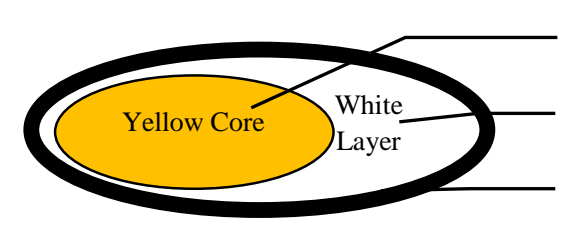

Core layer corresponded to the position of "Tatwa or phylosophical aspects"

Second layer corresponded to the position of "Susila or Ethical aspects"

Outer layer corresponded to the position of "Upachara or Tangible aspects"

Figure 2. Rule of Correspondence Metaphor Structure of Egg Theory with Three Entities of Taksu in Creative Work or Creative Activity

Hinduism, namely the concept of "tri frame of taksu cosmology". They see that a job is said to be metaksu when it is built with a three-skeletal structure, namely: tatwa or tough, susila or ethic, and upachara or tangible ritual. In var-ious participatory observation activities com-bined with in-depth interview activities, it was concluded that every creative work/product or creative activity carried out generally always involved the three entities of the taksu cos-mology framework. From tatwa elements or thought studies, the subject of research always starts from the concept of creating creative products or creative activities. In essence, there are always logical reasons why a work is done or creative activity is done with consideration and specific ways (Why aspects). The next in-dication, the subject of research always for-mulates certain rules related to how a work should be done or activity should be carried out (aspects of the How). Furthermore, the subject of research determines what must be displayed in creative products or their creative activities in order to meet the initial rules and concepts that have been formulated (What aspect). The crystallization of the three entities or the three basic frameworks of creativity and entrepreneurship resulted in a metaphor for the structure of an egg (egg theory). When the correspondence rule is applied to the main structure of an egg which also consists of three layers, as presented in Figure 2, then: (a) egg yolk as the core layer, can be corresponded to the position of the tatwa (philosophical aspects); (b) white part as the second layer, can be corresponded to the position of susila (ethical aspects); and (c) eggshell as the skin or outer layer, the position is commensurate with upachara or tangible aspects.

The three concepts of the taksu cosmological framework turned out to be coherent with Sinek's Golden Circle theory (Sinek, 2009). The Golden Circle theory divides the main structure of creative economic entrepreneurial works or activities, including (a) Why (aspects of apprehension); (b) How (aspects of ethical rules or procedures); and (c) What (physical aspect or final appearance). These three entities, when they are able to be harmonized by their makers properly, are believed to be able to produce creative works that are very expressionist, have strong appeal, and are of high value (Wiryomartono, 2014, p. 72). 
Likewise, the concept of entrepreneurial character, based on the results of the source and research data triangulation, it was indicated that entrepreneurial character converged on the three main group attributes, namely: (a) mindsets; (b) heart-sets; and (c) action sets. Some informants also pursued the formulation of entrepreneurial character development strategies from the perspective of the local wisdom of Balinese, namely the concept of Catur Guru (four guiding roles or themes). The concept includes: (a) rupaka teacher (family role contribution); (b) pengajian teacher (the school parties role contribution); (c) wisesa teacher (community role contribution); and (d) swadhyaya teacher (spiritual value as the justification control over the role of the other three elements). Based on informants' views, the three elements (family, school, and community) coordinate, unite commitment and share roles in forging the character of students. Starting from home, school, and when in their community life, by placing spiritual values as a justification for the role of these three elements.
Based on the triangulation of data obtained from the study of learning program documents, participatory observation of classroom learning activities; in the industrial world, followed up by in-depth interviews with key informants, conceding to some of the essences of values and perspectives on creative economic entrepreneurial character development that needs to be instilled in students. From the results of crystallized data triangulation, seven perspectives on the character development of creative economic entrepreneurs that are integrally idealized are pursued, namely the SEMESTA Sapta Pratyaksa (Table 1 and Figure 3).

Triangulation of research data from the results of participatory observation and indepth interviews also confirmed the implementation framework of creative economic entrepreneurial character development through three stages: (1) input; (2) process; and (3) output. The description of the three stages can be understood through the flow chart presented in Figure 4.

Table 1. Seven Creative Economy Entrepreneurial Character Development Perspectives (SEMESTA Sapta Pratyaksa)

\begin{tabular}{|c|c|}
\hline $\begin{array}{c}\text { Seven } \\
\text { Perspectives }\end{array}$ & Perspective Descriptions \\
\hline $\begin{array}{l}\text { Scientific } \\
(S)\end{array}$ & $\begin{array}{l}\text { The planning, implementation and evaluation perspectives on character development } \\
\text { programs that prioritize ways of thinking and acting according to scientific logic } \\
\text { procedures (scientific procedure). }\end{array}$ \\
\hline $\begin{array}{l}\text { Engineering } \\
(E)\end{array}$ & $\begin{array}{l}\text { The planning, implementation and evaluation perspective of character development } \\
\text { programs that involve aspects of engineering or engineering design, for example: } \\
\text { construction, ergonomics, composition, and structure). }\end{array}$ \\
\hline $\begin{array}{l}\text { Mathematical } \\
\text { (M) }\end{array}$ & $\begin{array}{l}\text { The planning, implementation and evaluation perspective of character development } \\
\text { programs involving elements and numerical calculation procedures. }\end{array}$ \\
\hline $\begin{array}{l}\text { Economical } \\
(E)\end{array}$ & $\begin{array}{l}\text { The planning, implementation and evaluation perspective of character development } \\
\text { programs involving essential elements of economics (business-model) such as: } \\
\text { accounting, logistics management, production, marketing, and resource management } \\
\text { (financial, human resources, tools and equipment resources) }\end{array}$ \\
\hline $\begin{array}{l}\text { Sosiocultural } \\
(S)\end{array}$ & $\begin{array}{l}\text { The planning, implementation and evaluation perspectives of character development } \\
\text { programs that involve consideration of social and cultural factors that develop in a } \\
\text { particular community, such as: the values of philosophy and norms of local wisdom, } \\
\text { community behavior preferences, social structure, community interaction patterns and } \\
\text { so on. }\end{array}$ \\
\hline $\begin{array}{l}\text { Technological } \\
(T)\end{array}$ & $\begin{array}{l}\text { The planning, implementation and evaluation perspective of character development } \\
\text { programs that involve consideration of the utilization of devices, tools/equiments or } \\
\text { media used in everyday life. }\end{array}$ \\
\hline $\begin{array}{l}\text { Artistical } \\
\text { (A) }\end{array}$ & $\begin{array}{l}\text { The planning, implementation and evaluation perspective of character development } \\
\text { programs that involve consideration of aspects of beauty, texture, composition, aesthetic } \\
\text { values in creating a work. }\end{array}$ \\
\hline
\end{tabular}




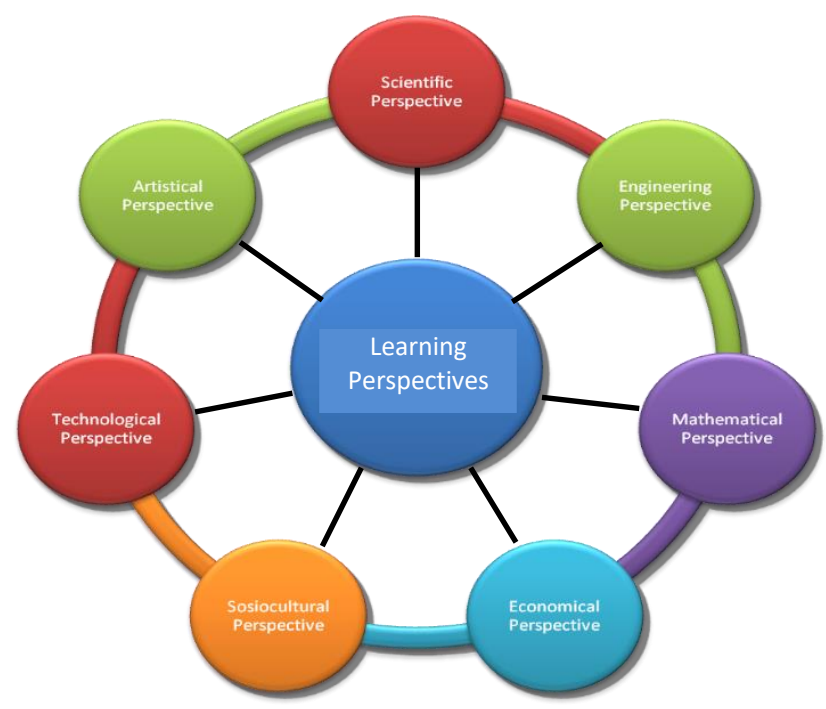

Figure 3. Seven Learning Perspectives in Developing Creative Economy Entrepreneurial Character (SEMESTA Sapta Pratyaksa)

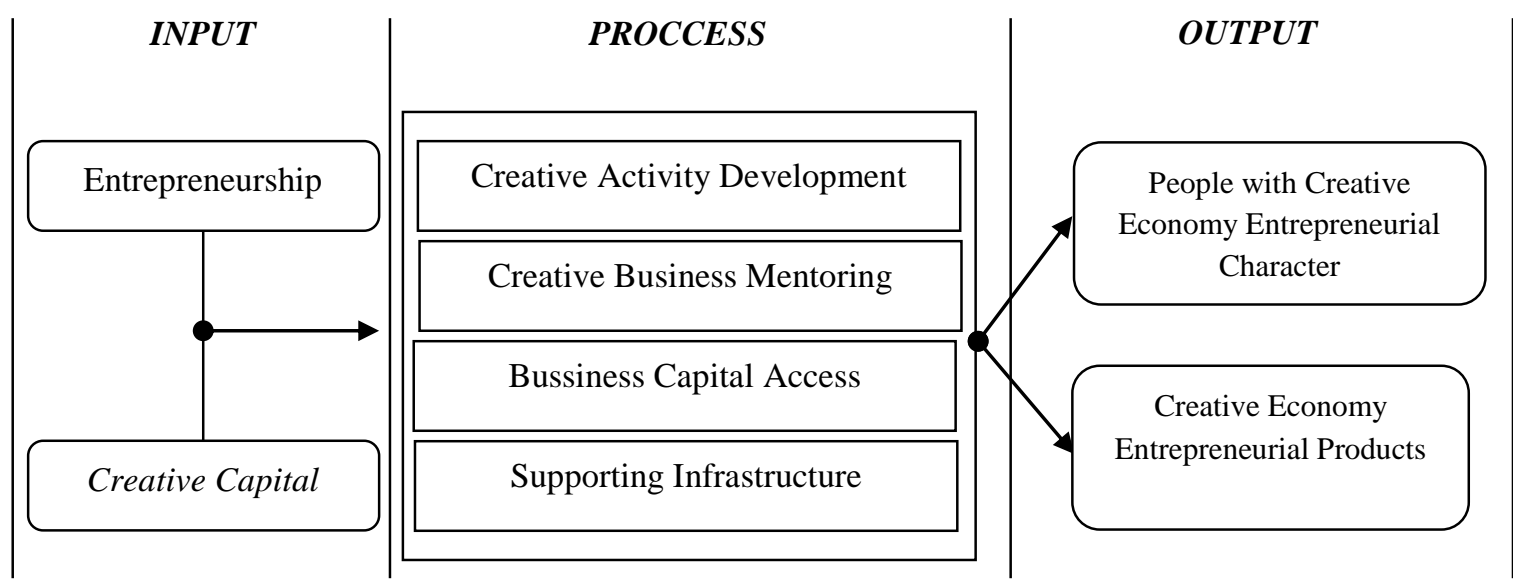

Figure 4. Stages of Creative Economy Entrepreneurial Character Development

The praxis of creative economic entrepreneurial character development generated from the crystallization of understanding and experience of the informants turned out to be coherent with macro strategies implied in "Creative Economy Green Paper for the Nordic Region" compiled by Fleming (2007, pp. 1112) in the form of six key scenarios (key themes). The six scenarios can be adapted in the form of (1) growth of entrepreneurial character and creative spirit in the frame of academic activities (intracurricular); (2) developing creative activities (extracurricular); (3) the formation of creative communities in schools; (4) building critical interactions between creative economic actors and the school parties (school management, teachers and students); (5) facilitating the acquisition of costs or capi- tal in pioneering creative businesses (school budgets, government assistance or third party funds/sponsors); and (6) providing supporting infrastructure as a means/place for expressing creative ideas and products for teachers, students and all school members.

\section{Concept and Implementation of Culture of Sustainable Development in Vocational Schools}

Crystallization of research findings data obtained by the informants' views converged on defining school culture as a standard set of beliefs or assumptions, values and norms and physical activities which became guidelines for thinking and acting of the School community member in order to foster a shared commitment 
to realizing the institution's vision and mission. In the context of the culture of sustainable development, several research informants alluded to metaphors stemming from the local wisdom of Balinese Hinduism, namely the symbolic meaning of Dewi Saraswati as the goddess of science and art very relevant to the spirit of sustainable development, as shown in Figure 5.

The symbolic meanings referred to by the informants include: (1) the never-ending process of learning in the symbolic meaning of genitri or chain; (2) learn to be wise in the symbolic meaning of white swans; (3) learning by reading various literature in the symbolic meaning of petals or lontar; (4) learning by listening in the symbolic meaning of a winal guitar as musical instrument; (5) learning by practicing (hands-on experiences) in symbolic meaning with four arms; (6) learning with appreciation that science is sacred, giving leverage effect to authority and attractive effect for those who possess it in the symbolic meaning of white lotus, beautiful peacocks and goddesses. These symbolic meanings are in line with the theory of accelerated learning (Meier, 2000): (1) somatic namely learning by practicing; (2) auditory which is learning through the sense of hearing; (3) visual, which is learning through the sense of sight, and (4) intellectual, namely learning through intellectual processes (SAVI).

Related to the strategy of civilizing sustainable development, based on the explanation of the informants in several in-depth interview sessions, it can be mapped three forms of intervention strategies that are sorted based on main priority ethical considerations: (1) intervention strategies through sociocultural approaches, which prioritize the generation of individual inner motivation through social-engineering techniques, rewarding or appreciation; (2) intervention strategies through figure modelling approaches using the adherence of figures from external or internal schools, who put forward examples of the success of certain figures to tap the motivation of others to follow in the footsteps of their achievements; and (3) intervention strategies through the functionalization of the school's organizational structure, which is the last choice when previous strategies are considered unsuccessful. It is because the third strategy is more intimidating, which is motivation arises because of an individual's external drive, and its effects tend to be temporary (not permanent). The three intervention strategies for continuous development culture when idealized integratively produce the pattern shown in Figure 6.

The findings of ethnographic research turned out to have coherence with one of the grounded research findings of Raharjo (2013). One of the results of research recommended three types of intervention strategies, namely: (1) structural intervention; (2) figure intervention; and (3) cultural intervention. However, his research does not confirm which strategy prioritizes ethical use.

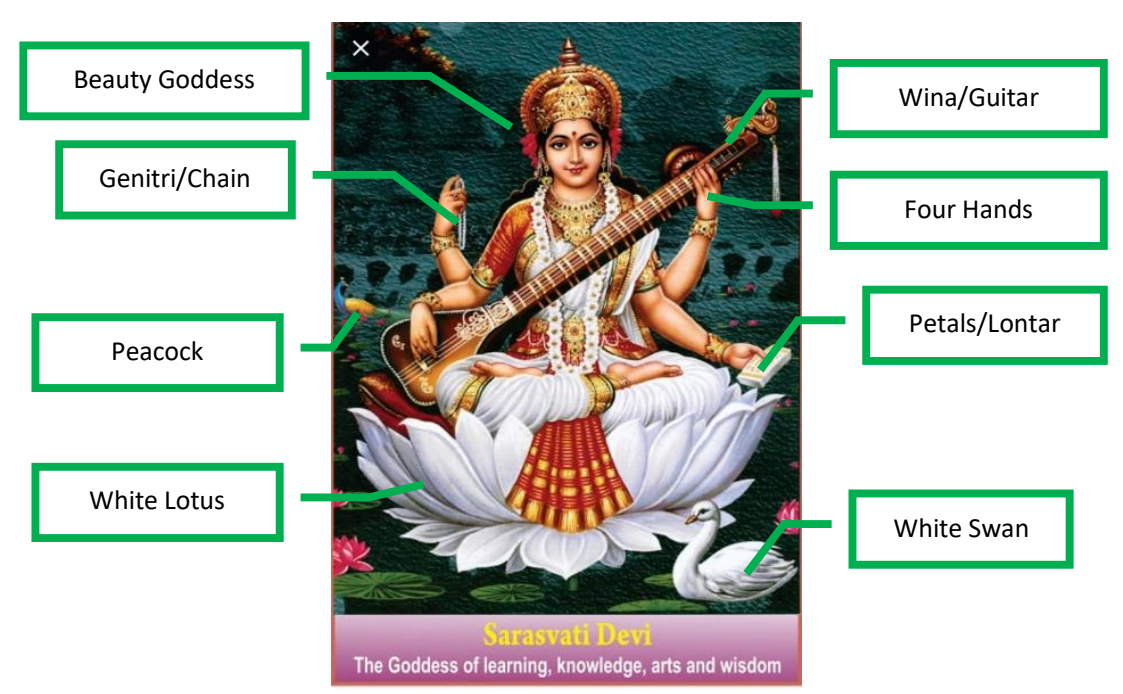

Figure 5. Goddess Saraswati as the Goddess of Science and Art 


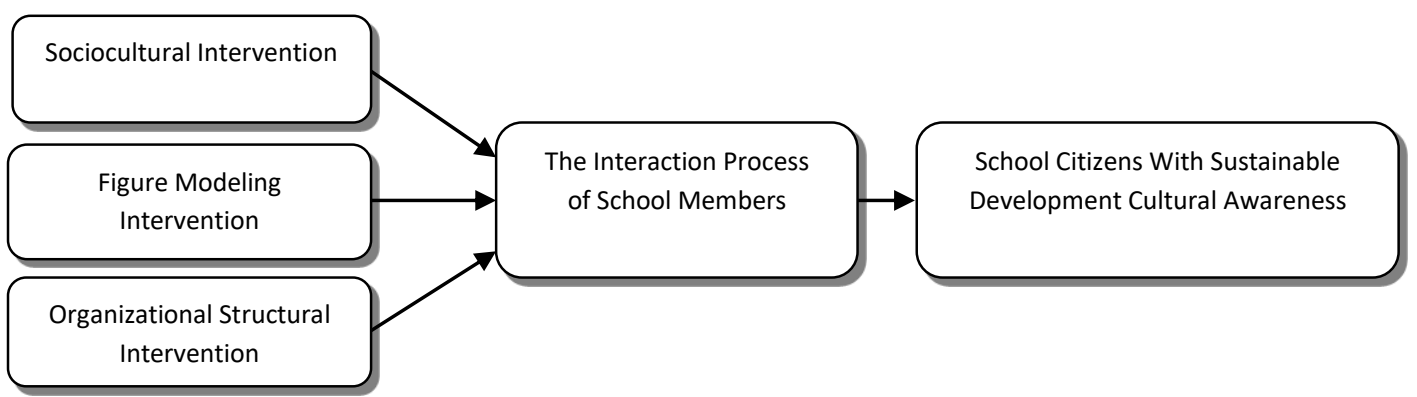

Figure 6. Strategic Intervention of Sustainable Development Culture in Vocational Schools

\section{Concept and Implementation of Partner- ship in Education Stakeholders in Vocation- al Schools}

Based on the perceptions of the research informants, if it is drawn to its essence, it defines Vocational education stakeholders as individuals, groups or institutions that participate critically in the progress of the long-term development of educational activity in Vocational Schools, to produce a various consensus decided by all elements democratically. From these definitions, two main substances can be drawn: (1) Vocational education stakeholders can be individuals, groups or institutions; and (2) in their interactions, stakeholder partnerships focus on participation, consensus formation (joint commitment) and the decisionmaking process is carried out democratically.

Furthermore, by combining the essence of information summarized from the views of the research informants, there were identified four groups of vocational education stakeholders: (1) the community, both individually and in groups; (2) educational institutions (VHS) along with all of their elements; (3) business and industrial actors, both individuals and institutions; and (4) government parties. Based on in-depth interview data, it was identified that each of these groups had different contributions and interests. For example, as an individual, parents of students have an interest in sending their children to a vocational school. As part of a community group, they act as social control of the quality education policy of the Vocational School. Also, educational institutions (VHS) and all of their elements play a role as organizers of vocational education activities. Next, business and industry players (Dunia Usaha dan Dunia Industri or DuDi), besides acting as vocational school users, they should also participate in providing learning experiences about the world of work for voca- tional students, and as critical partners of Vocational Schools in terms of updating vocational education curriculum content. Meanwhile, the government, in addition to providing financial assistance to support vocational education activities, also acts as a provider of the legal umbrella (rules of the game) for every vocational education activity in vocational schools.

Based on in-depth interview data with several key informants from each of the Vocational education stakeholder group, and also through participatory observation, identified several forms of partnership activities between the Vocational School and other stakeholders or stakeholder groups. For example, school partnerships with families (parents) in handling cases of violations of juvenile discipline and delinquency, through guidance and counseling services in terms of in-school service or home visit. Besides, the partnership of the Vocational School with the business and industry in terms of: (1) workers recruitment through a special labor market program; (2) CSR (corporates social responsibility) programs in the form of resources sharing in terms of the procurement of facilities for vocational practices requiring very expensive investment costs if provided by the Vocational School; (3) industrial practice (workplace learning) for vocational students; (4) development of teaching staff competencies; and (5) development of vocational education curriculum (VHS).

The results of in-depth interviews with business actors and creative industries provide information in the form of important experience sharing as input for the development of vocational curriculum content in the context of changing perspectives on creative economic entrepreneurship management. The pattern crystallization that can be generated is related to changes in the informants' perspective of creative economic entrepreneurial management: the need for a shift in the quantitative 
economic paradigm towards the qualitative economic paradigm. In essence, the crystallization of the pattern has coherence with the comparative study of blue ocean strategy and red ocean strategy theory by Kim and Mauborgne (2005). In short, both the sharing of experience from business people and the creative industry or the blue ocean strategy theory recommends shifting the mindset of the owning economy towards the pattern of sharing economy thinking.

From the perspective of the owning economy, all business supporting resources are held or owned by the business owner. The impact is that the investment costs are very high, and require the allocation of costs for the maintenance of assets and business infrastructure. In the perspective of sharing economy, all business support resources do not have to be owned by the business owner. However, by utilizing the resources of other parties who become business partners. It provides a chain advantage for the competitiveness of the products or services produced. The investment costs for the procurement and maintenance of business facilities and infrastructure can be more efficient. It will impact the smaller production costs, where the subsequent impact is the cost of goods sold (COGS) for the offering products or services to be more competitive (cheaper).

Regarding the business revenue sector, Blue Ocean Strategy recommends adding channels and implementing value chain policies, so that revenue streams (income structure) are greater because of the addition of income channels and added value at each stage of the business circulation carried out. In essence, to win a business competition in the creative economy era does not need to be done in the old way (red ocean strategy), which is bleeding with a head to head competition pattern. There are still many creative ways to win the business competition more elegantly, for example, by creating a new market niche, offering more value to certain customer segments, such as the concept of home shopping or the convenience of shopping from home with delivery services. The key to victory in business competition in the era of the creative economy lies in creativity in reformulating the "business model".

The formulation of a business model crystallized from sharing the experiences of research informants covers nine aspects of consideration: (1) aspects of the cost structure: material costs, labor costs, overhead costs, etc; (2) revenue aspects: income at the stage of creation, production, distribution and commercialization of creative products; (3) more value offered to consumers (value proposition), determined based on the mapping of consumer behavior (consument behavior survey); (4) aspects of business activities that become mainstay (key activity), determined based on the feasibility study; (5) aspects of key resources, determined based on business circulation analysis; (6) aspects of key partners: investment, production, marketing, distribution, and transaction mechanism partners (cash or non-cash with financial technology or fintech services); (7) the channel aspect that is the mainstay (key channel), determined based on business circulation analysis; (8) aspects of consumer relations (consument relationship), reviewed through customer satisfaction surveys; and (9) aspects of market segmentation, determined based on the feasibility study. The nine aspects of the business model can be converted into analytical templates known as business model canvas (Kasali, 2017), shown in Figure 7.

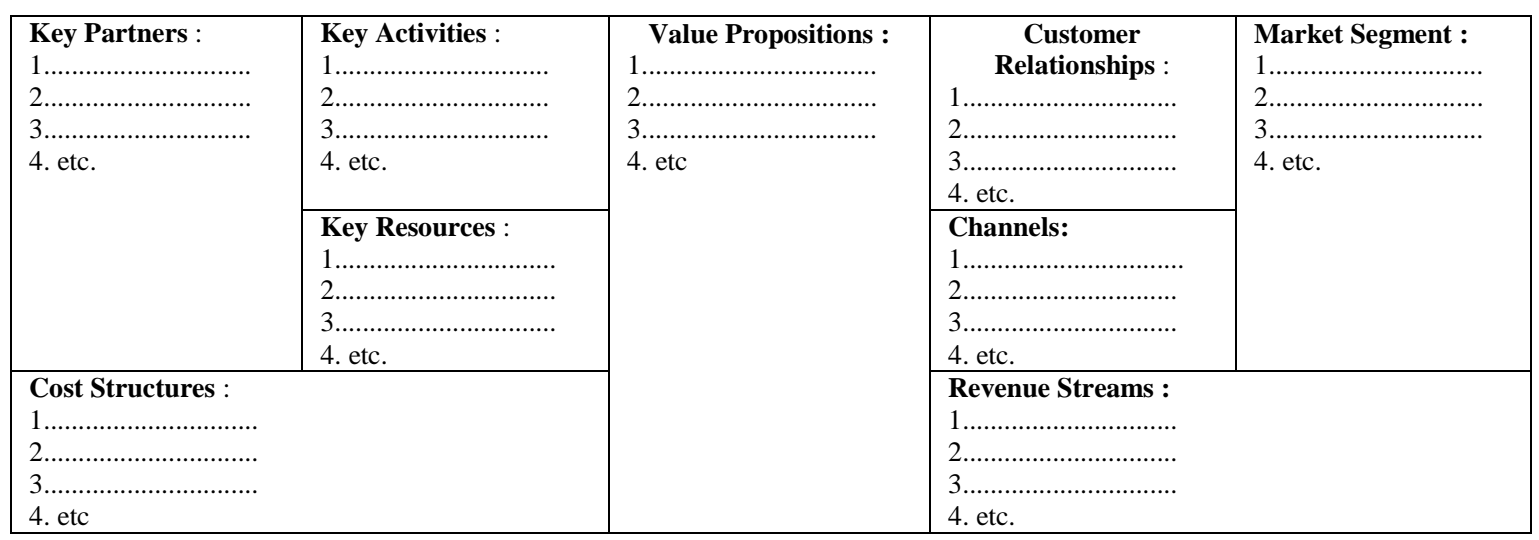

Figure 7. Business Model Canvas Template Source: adapted from Kasali (2017) 


\section{CONCLUSION AND SUGGESTIONS}

\section{Conclusion}

Based on the results of data triangulation revealed through in-depth interviews, participatory observation, documentation studies and internet site tracing, some conclusions can be drawn as follows: (1) The concept of vocational education (VHS) is a form of secondary level vocational education program that combines vocational learning and general learning, so as to be able to equip graduates with vocational skills (industrial specific skills and employerspecific skills) and life skills as capital the basis for entering the workforce, entrepreneurship and or continuing education. The implementation of the concept is that the learning moves in a sequential spiral (such as insect repellent) from: (a) expert centered learning; (b) extends to work-based learning (in the lab/school workshop), workplace learning (in the industrial world); and (c) expanding into life-based learning to equip students with fundamental skills and generic-work skills.

The concept of creative economic entrepreneurial character development in VHS refers to the concept of the Taksu's three entity, including tatwa as the philosophical aspects, susila as the ethical aspects, and upachara as the tangible aspects. Meanwhile, the implementation integrates the seven perspectives (SEMESTA) on the study of creative economic entrepreneurship learning, including perspectives: scientific, engineering, mathematical, economic, sociocultural, technological, and artistic.

The concept of a sustainable development culture in Vocational Schools is understood as a set of standards of beliefs or assumptions, values and norms and physical activities that serve as guidance for thinking, and acting in the community members of the school community sustainable development in all elements to realize the vision and mission of the VHS. Furthermore, intervention strategies for civilizing sustainable development in Vocational Schools (VHS) include: (a) sociocultural interventions; (b) figure interventions; and (c) organizational structural intervention.

The concept of education stakeholders in Vocational High Schools (VHS) is individuals, groups or institutions that participate critically on the long-term development progress of edu- cational activity in VHS, in order to produce a various consensus that is decided democratically by all elements. The scope of the partnership includes (a) family and school partnerships; (b) school and business and industry partnerships; and (c) school parties with the governmental institution partnerships.

\section{Suggestions}

The findings of cultural patterns and value systems (shared cultural patterns and values) from ethnographic research are essential to be published or disseminated to the stakeholders of vocational education. That way, there will be a similar perspective in planning, implementing and evaluating the implementation practices of vocational education among stakeholders, starting from the provincial education office of Bali, business and industry in Bali, vocational curriculum developers in Bali and community observers of vocational education, especially in the context of character development of creative economic entrepreneurship through a culture of sustainable development and vocational stakeholder partnerships.

\section{REFERENCES}

Fleming, T. (2007). A creative economy green paper for the Nordic Region. London: Nordic Innovation Centre. Retrieved from http://tfconsultancy.co.uk/reports/ CreativeEconomy_NordicRegion.pdf

Fraenkel, J. R., Wallen, N. E., \& Hyun, H. H. (2012). How to design and evaluate research in education (8th ed.). New York, NY: McGraw Hill.

Given, L. M. (2008). The SAGE encyclopedia of qualitative research methods. Thousand Oaks, CA: Sage Publications.

Kasali, R. (2017). Disruption. Jakarta: PT. Gramedia Pustaka Utama.

Kim, W. C., \& Mauborgne, R. (2005). Blue Ocean Strategy: How to create uncontested market space and make the competition irrelevant. Boston, MA: Harvard Business School.

Meier, D. (2000). The accelerated learning handbook: A creative guide to designing and delivering faster, more effective 
training programs. New York, NY: McGraw Hill.

Muhadjir, N. (2011). Metodologi penelitian: Paradigma positivisme objektif, phenomenologi interpretif, logika bahasa Platonis, Chomskyist, Hegelian \& Hemeneutik, paradigma studi Islam, matematik recursion, set-theory \& structural equation modeling dan mixed. Yogyakarta: Rake Sarasin.

Raharjo, N. E. (2013). Model pengembangan kultur sekolah berbasis karakter kewirausahaan di Sekolah Menengah Kejuruan. Dissertation, Universitas Negeri Yogyakarta. Retrieved from https://eprints.uny.ac.id/22738/

Sinek, S. (2009). Start with why: How great leaders inspire everyone to take action. New York, NY: Portfolio Peguin Group.
Sudira, P. (2016). TVET abad XXI: Filosofi, teori, konsep, dan strategi pembelajaran vokasional. Yogyakarta: UNY Press.

The Central Bureau of Statistics. (2016a). Keadaan ketenagakerjaan Agustus 2016. Jakarta: The Central Bureau of Statistics of Indonesia.

The Central Bureau of Statistics. (2016b). Keadaan ketenagakerjaan Provinsi Bali Agustus 2016. Denpasar: The Central Bureau of Statistics of Bali.

Wiryomartono, B. P. (2014). Perspectives on traditional settlements and communities: Home, form and culture in Indonesia. Gateway East: Springer Singapore. 